\title{
Revision of the genus Cordaites UNGER from the Permian of the Intrasudetic Basin (Broumov Formation, Olivětín Member, Czech Republic)
}

\author{
Zbyněk Šimůnek \\ Czech Geological Survey, Klárov 3/131, 11821 Praha 1, Czech Republic; (zbynek.simunek@geology.cz)
}

doi: $10.4154 / g c .2019 .16$

Article history:

Manuscript received June 06, 2019

Revised manuscript accepted September 10, 2019

Available online October 31, 2019

Keywords: Cordaites, Permian flora, Intrasudetic Basin

\begin{abstract}
Cordaitalean remains are not very common in the Permian of the Intrasudetic Basin (Czech Republic and Poland) and have usually been classified simply as Cordaites sp. Based on leaf morphology, venation and cuticles (where possible), five cordaitalean species are recognised: Cordaites cf. beinertianus, $C$. cf. affinis, C. cf. roesslerianus, C. cf. foliolatus and Cordaites sp. A. The determination of Cordaites leaves is difficult because of the variability and similarities between several species. The biggest leaf was determined as Cordaites cf. beinertianus. The cuticles of Cordaites cf. affinis resemble the cuticles of $C$. palmaeformis and C. radvanicensis, however, the latter is known only in a fragmentary state. Cordaites beinertianus and C. palmaeformis are very similar and are considered as conspecific by some authors. Cordaites affinis has generally smaller leaves. Cordaites cf. roesslerianus is comparable with C. principalis with which it is sometimes synonymised. $C$. cf. foliolatus is represented by a much narrower leaf than is typical for cordaitalean leaves from France. Cordaites sp. A is a relatively small leaf-form and differs from all other forms previously described.
\end{abstract}

\section{INTRODUCTION}

Cordaitalean remains from the Bohemian part of the Intrasudetic Basin have been known to palaeobotanists since the $19^{\text {th }}$ century [e.g. Cordaites platynervis (GÖPPERT, 1864) GRAND’EURY, 1877]. Since then, tens of Cordaites species have been described based on leaf morphology and venation. However, it has been shown that venation can be strongly influenced by both taphonomic and preservation conditions (CROOKALL, 1970). Moreover, many species have been described based on incomplete specimens, without their base, or apex, and such specimens are difficult to compare with other specimens only by the means of venation.

In reality, the situation is more complicated, because both leaf morphology and venation have some natural variability caused by the edaphic and climatic conditions in which the plant grew. The most stable feature seems to be the cuticle. Cordaitalean cuticles have been studied by FLORIN (1931), and more systematically by BARTHEL (1962, 1964, 1976), LEDRAN (1960, 1966), and RABITZ (1966). BARTHEL $(1962,1964,1976)$ found that one species [e.g. Cordaites principalis (GERMAR) GEINITZ] can have different cuticles, that he named Type 1 to Type 8. BARTHEL (1976) was aware of the problem of the correct determination of Cordaites species and came to the conclusion that it is not possible to distinguish three long-leaved Cordaites species $-C$. borassifolius (STERNBERG) UNGER, C. palmaeformis (GÖPPERT) WEISS and C. principalis (GERMAR) GEINITZ, and he suggested calling them "Cordaites sp." This interpretation helps to avoid problems in the determination of Cordaites species, but it does not enable recognition of the diversity of this group and/or the specification of the number of Cordaites species per locality. BARTHEL $(2009,2016)$ did not change his mind and classified all samples as Cordaites $\mathrm{sp}$.

From the quantity of Cordaites names, only Cordaites borassifolius, $C$. palmaeformis and $C$. principalis dominate in the palaeobotanical literature. As shown above, these species are understood by different authors in different ways, and only cuticles from the type material will help to solve the problem of the accurate determination of these species. Cuticles of Cordaites borassifolius were described as amphistomatic with dispersed stomata on the adaxial cuticle, and stomatiferous and non-stomatiferous bands on the abaxial cuticle (ŠIMU゚NEK et al., 2009). Studying cuticles of Cordaites palmaeformis was difficult due to poor preservation, but eventually the stomata were shown to be arranged in stomatal rows on both cuticles (ŠIMU゚NEK, 2015). A problem remains with Cordaites principalis, because its holotype is preserved as an impression in fine-grained sandstone that does not allow cuticular study (ŠIMU゚NEK, 2015).

Some cordaitalean remains were discovered during the study of flora from the Olivětín Member in the Intrasudetic Basin. Because some of these remains were large and some contain coal matter suitable for cuticular study, description of these specimens by the author was possible.

\section{MATERIAL AND METHODS}

The specimens are stored in the collections of the National Museum in Prague and the Museum of Eastern Bohemia in Hradec Králové (No. 74574 and 74575). All specimens came from the Otovice locality (National Museum), and Otovice, Černý potok (Black Creek) limestone (Museum of Eastern Bohemia). All were from the Permian (latest Asselian) Broumov Formation, Olivětín Member (OPLUŠTIL et al. 2016, Table 1). Three Cordaites specimens were macerated and slides No. 698/1-16, 699/1 and 700/1-4 prepared.

The method used involved maceration in Schulze's reagent, as described previously by KERP (1990), KRINGS \& KERP (1997) and KERP \& KRINGS (1999). Coalified fragments of 
Table 1. Stratigraphic table of the youngest part of the Intrasudetic Basin. Adopted according to OPLUŠTIL et al. (2016). Remark: Time intervals of gaps between younger units are not known.

\begin{tabular}{|c|c|c|c|c|c|c|}
\hline \multicolumn{2}{|c|}{ Global scale } & \multicolumn{2}{|c|}{ Regional scale } & Formation & Member & Group of \\
\hline \multirow{2}{*}{ Tri. } & Middle & & & Bohdašín & & \\
\hline & \multicolumn{6}{|c|}{ Híatus } \\
\hline \multirow{7}{*}{$\begin{array}{l}\frac{c}{\mathbb{D}} \\
\frac{\mathbb{E}}{\frac{1}{D}} \\
0\end{array}$} & ?Lopingian? & Zechstein & & Bohuslavice & & \\
\hline & \multicolumn{6}{|c|}{ Hiatus } \\
\hline & Guadalupian & \multirow{5}{*}{ Rotliegend } & & Trutnov & & \\
\hline & \multirow{4}{*}{ Cisuralian } & & & \multicolumn{3}{|c|}{ Hiatus } \\
\hline & & & \multirow{3}{*}{ Asselian* } & & Martínkovice & \\
\hline & & & & Broumov & \begin{tabular}{|l|} 
Olivětín \\
Nowa Ruda
\end{tabular} & \\
\hline & & & & \multirow{2}{*}{ Chvaleč } & Bečkov & \\
\hline \multirow{4}{*}{$\begin{array}{l}\frac{1}{\lambda} \\
\frac{1}{0} \\
\frac{\sigma}{c} \\
\frac{c}{c} \\
0 \\
0 \\
0\end{array}$} & \multirow{3}{*}{ Gzhelian } & \multirow{4}{*}{ Stephanian } & C & & Vernéřovice & Rybníček \\
\hline & & & $B$ & & Hiatus & \\
\hline & & & Saberian & Odlav & Jívka & Radvanice \\
\hline & Kasimovian & & Barruelian & & "Žaltman arkc & es" \\
\hline
\end{tabular}

leaves were separated from the rock by needle or by hydrofluoric acid (HF) digestion. These fragments were bleached in Schulze's reagent $\left(40 \% \mathrm{HNO}_{3}\right.$ with crystals of $\left.\mathrm{KClO}_{3}\right)$ for 3-7 hours. After the treatment in Schulze's reagent, cuticles were washed in water, subsequently immersed in $2 \%$ or $10 \%$ potassium hydroxide $(\mathrm{KOH})$ and finally rinsed in distilled water. Some cuticles were stained with safranin, Bismarck brown, malachite green or neutral red (KRINGS, 2000) for 1 to 2 hours to accentuate the anticlinal walls and stomata. Before embedding in glycerine-gelatine slides, the cuticles were dehydrated in pure glycerine.

\section{GEOLOGICAL SETTING}

The Intrasudetic Basin, which is situated along the eastern margin of a suite of Late Palaeozoic Bohemian continental basins (Fig. 1), is the most important among the Sudetic basins. Structurally, the Intra-Sudetic Basin is a complicated NW-SE-elongated syncline with up to $5 \mathrm{~km}$ of infill that occupies an approximately $1800 \mathrm{~km}^{2}$ area, of which about one third is located in the territory of the Czech Republic (formerly Czechoslovakia). Deposition spans a wide stratigraphic interval from the middle Visean to the Triassic and includes several hiatuses. Continental deposits unconformably overlie Saxo-Thuringian crystalline complexes

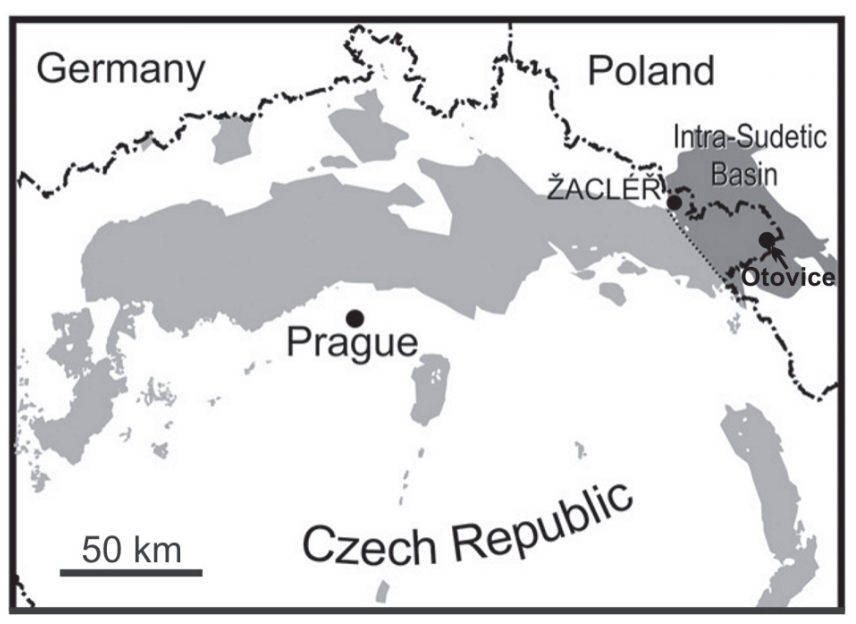

Figure 1. Map of the Czech Republic with Permo-Carboniferous basins and the studied locality. of Pre-Cambrian to Early Palaeozoic age (TÁSLER et al., 1979, BOSSOWSKI, 1995). Visean sediments in Poland consist of a few kilometres of fluvial to alluvial-fan strata with intercalated marine to deltaic deposits. They are followed in Poland by Serpukhovian (early Namurian) fluvial and coal-rich deposits of the Wałbrzych Formation. In Bashkirian times, the depositional center enlarged further to the south along a tectonically active western basin margin. This resulted in deposition of the Late Bashkirian-Early Moscovian Žacleř Formation (Yeadonian-Bolsovian), with about 60-80 coal seams in three members. Locally important coal seams of Kasimovian - Gzhelian (Cantabrian to Saberian) age occur only in the Czech part of the basin in the Odolov Formation (Svatoňovice and Jivka members) (Table 1).

The Stephanian/Permian Chvaleč Formation is mostly composed of coal-barren fluvial red beds and contains only one thin coal seam in the Vernéřovice Member. Lacustrine horizons a few tens of metres thick, with bituminous limestones and shales are rarely intercalated in red beds (Bečkov Horizon). The overlying Broumov Formation contains the Nowa Ruda, Olivětín and Martínkovice members that correspond mostly to the Asselian (OPLUŠTIL et al. 2016). The Nowa Ruda Member is formed mostly by thick complexes of rhyolite tuffs and tuffites, The Olivětín Member contains fossiliferous "Walchia" shales several tens of metres thick and thin bituminous shales and Ruprechtice and Otovice limestones. The Martínkovice Member also contains limestone horizons, but only animal fossils have been discovered so far. The Upper Permian Trutnov and Bohuslavice formations are composed of red and brown mudstone and sandstone deposits; and the Middle Triassic Bohdašín Formation is represented mostly by white sandstones.

\section{SYSTEMATICS}

Order Cordaitanthales MEYEN, 1984

Family Cordaitanthaceae MEYEN, 1984

Genus Cordaites UNGER, 1850

Type species Cordaites borassifolius (STERNBERG) UNGER, 1850

As mentioned in the Introduction, there are difficulties with the systematics of Cordaites leaves. More than 40 cordaitalean species have been described based on leaf adpressions from Europe, 
defined on the shape, dimensions and venation type. Even with complete, or nearly complete leaves, there can still be difficulties in classifying specimens to particular species, because the venation is often poorly preserved due to taphonomic processes (CROOKALL, 1970).

About 15 species of Cordaites UNGER and Poa-Cordaites GRAND'EURY ex BRONGNIART have been described from the Stephanian and Permian, or reported from these strata. These species were compared with specimens found in the Otovice localities but the latter are problematic because their cuticles are poorly preserved and so cannot be used in species determination.

In both museums, seven fragments, probably belonging to four or five species, were selected for study. CROOKALL (1970) only described five species from Great Britain. The last comprehensive paper on cordaitaleans was published by LEDRAN (1966) who described 22 species from France. She also tried to describe the cuticles but they were usually poorly preserved and only in a few cases did they add significant information to supplement the morphological description. BARTHEL $(1962,1964)$ distinguished in Cordaites principalis several types of cuticles and considered Cordaites borassifolius, C. palmaeformis and $C$. principalis as indistinguishable from each other (BARTHEL, 1976, 2009, 2016).

Specimens from the Otovice locality demonstrate the variability in leaf shape, dimension and venation. Here, comparison of these specimens will be made with other specimens described from the uppermost Stephanian and Permian.

\section{Cordaites cf. beinertianus (GÖPPERT, 1841) GRAND'EURY, 1877}

(Fig. 2a, h, i; PI. 1, Figs. a, b)

1841 Noeggerathia beinertiana GÖPPERT, Vol. 5-6, p.108, pl. 12, fig. 3 .

1877 Cordaites beinertianus GÖPPERT; GRAND'EURY, p. 215. 1914 Dorycordaites beinertianus (GÖPPERT) GRAND'EURY; Bureau, p. 304, Atlas, 1913, pl. 66, fig. 1.

Description: The leaf is lanceolate with a bluntly pointed apex. The fragment is $565 \mathrm{~mm}$ long and $97 \mathrm{~mm}$ wide. The venation is very fine and dense, 45-60 veins per $\mathrm{cm}$ in different parts of the leaf (Fig. 2a, h, i; Pl. 1, Figs. a, b).

Remarks: The complete leaf may have been more than 600 $\mathrm{mm}$ long, and because its right margin is enrolled (Fig. 2a), it could be $110-120 \mathrm{~mm}$ wide. The holotype of Cordaites beinertianus (GÖPPERT, 1842) represents the basal half of a leaf. It is wedge-shaped, widening from $3 \mathrm{~mm}$ (base) to $55 \mathrm{~mm}$ (in the middle) along its length of $170 \mathrm{~mm}$. The veins are very thin, and it seems from the picture that there are about 30 veins per $\mathrm{cm}$. As the apex is not preserved, determination by means of venation only is uncertain. The type locality of Cordaites beinertianus is the Charlottenbrunn (nowadays Jedlina Zdrój), of Poland and is probably Bolsovian in age. This combination was used for the first time by GRAND'EURY (1877) in comparison with Cordaites affinis, but $C$. beinertianus was not formally transferred to the genus Cordaites. GRAND'EURY (1877) used this name without description, only with reference to (GÖPPERT, 1842). C. beinertianus was also reported from the Upper Stephanian (BUREAU, 1914), though it is not known that these young specimens are of the same species as the holotype.

This specimen is also similar to Cordaites palmaeformis, however the lectotype represents several leaf fragments 160-180
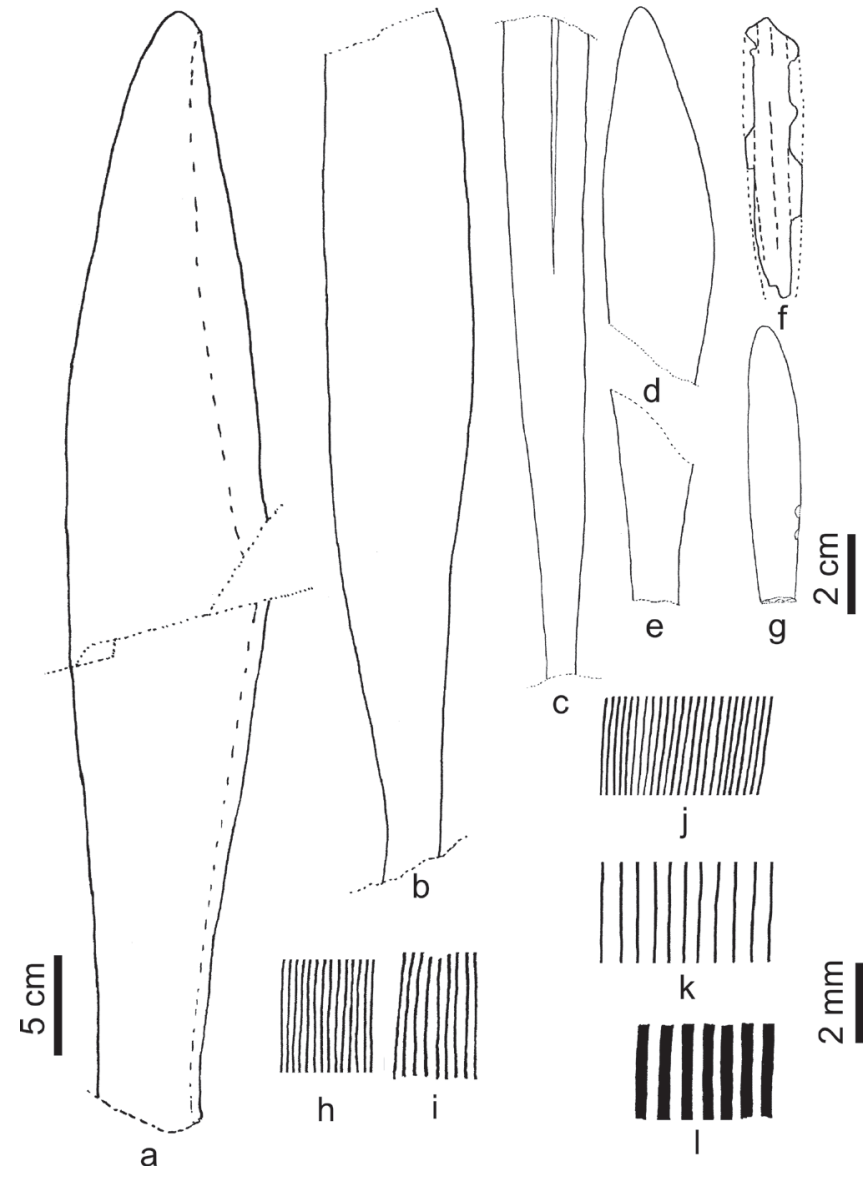

Figure 2. Shapes and venations of Cordaites leaves: a. - Cordaites cf. beinertianus, b. and c. -Cordaites cf. affinis, d. and e. - Cordaites sp. A; f. - Cordaites cf. roesslerianus, g. - Cordaites cf. foliolatus; Scale bars: $\mathrm{a}=5 \mathrm{~cm} ; \mathrm{b}-\mathrm{g}=2 \mathrm{~cm}$. Venations of leaves: h, i - Cordaites cf. beinertianus (fig. a), j - Cordaites cf. affinis (fig. b), k - Cordaites sp. a (fig. d), I - Cordaites cf. roesslerianus (fig. f). (Left scale bar is only for a; right upper scale bar is for $\mathrm{b}-\mathrm{g}$ and left lower scale is for $\mathrm{h}-\mathrm{l}$ ).

mm long and 12-20 mm wide (ŠIMŮNEK, 2015). Other specimens figured by GÖPPERT (1852) also do not have a preserved apex, which is an important diagnostic feature, but the leaves are wider, up to $50 \mathrm{~mm}$ wide. GÖPPERT (1852) did not specify the venation density; he only noted that the venation was fine and dense. Only subsequent authors more precisely defined the venation density: GEINITZ (1855) - 3-4; WEISS (1871) - 3-5 and ZEILLER (1886-1888) - 8-12 veins per mm. CROOKALL (1970) mentioned 35-50 veins per mm. This confusion may be because each specimen came from a different country and stratigraphy. The lectotype of Cordaites palmaeformis came from the Langsettian of Wałbrzych in the Intrasudetic Basin (ŠIMŮNEK, 2015), however the other syntype (GÖPPERT, 1852, pl. 16, fig. 2) is from the Upper Silesian Basin. The leaves of Cordaites palmaeformis are amphistomatic (ŠIMŮNEK, $2015)$, with stomata on both cuticles arranged in rows. One cuticle (probably adaxial) has 5-6 rows per $\mathrm{mm}$, whilst the second cuticle (probably abaxial) has 12-16 rows per mm. These densities correspond to the densities of fine veins in the adpressions, and also correspond to the specimen from Otovice. However, there is a large stratigraphic distance between these specimens, and cuticles from this specimen from Otovice are not known. GÖPPERT (1852) compared Cordaites palmaeformis with $C$. beinertianus. 


\section{Cordaites cf. affinis GRAND'EURY, 1877}

(Fig. 2b, c, j; PI. 1, Fig. c-e; PI. 2)

1877 Cordaites affinis GRAND'EURY; GRAND'EURY: p. 215-216, pl. XVIII, figs 6.7.

1896 Cordaites (Dorycordaites) affinis GRAND'EURY; RENAULT: p. 344, pl. LXXXVI, fig. 17.

Material: Two specimens. National Museum and Museum of East Bohemia (No. 74574). Cuticle slides 698/1-16 have been prepared from specimen 74574 .

Description: Two incomplete leaves. The larger (Pl. 1, Fig. c) is $215 \mathrm{~mm}$ long and $36.5 \mathrm{~mm}$ wide. Maximum leaf width is below its middle. The second specimen (Pl. 1, fig. e) is a leaf fragment $165.5 \mathrm{~mm}$ long and $20.5 \mathrm{~mm}$ wide in its upper part. This leaf was probably thin and lacerated in its upper part. The venation is the same in both specimens, formed by very thin veins with density of 55 veins per $\mathrm{cm}$.

Cuticles are very poorly preserved with details only visible by staining with safranin, malachite green or neutral red. It is difficult to distinguish adaxial and abaxial cuticles as both probably have stomatal rows and non-stomatiferous bands. Cuticles on Pl. 2, Figs a, b come from the same leaf fragment and were stained in malachite green. Pl. 2, Fig. a probably represents an adaxial cuticle. Dark bands $120-170 \mu \mathrm{m}$ wide are distinguishable from light bands around $60 \mu \mathrm{m}$ wide. Pl. 2 Fig. b probably belongs to an abaxial cuticle. The lighter bands on the adaxial cuticle probably correspond to stomatal rows on the abaxial cuticle and darker bands to non-stomatiferous bands (costal fields).

Abaxial cuticle (Pl. 2, Figs b-h). The cells are differentiated into $90-160 \mu \mathrm{m}$ wide non-stomatiferous bands and 50-60 $\mu \mathrm{m}$ wide stomatal rows. In contrast to the adaxial cuticles, the stomatal rows are darker than the non-stomatiferous bands. The cells of the non-stomatiferous bands are oblong with straight or slightly bent walls, $15-22 \mu \mathrm{m}$ wide and $45-80 \mu \mathrm{m}$ long. The structure of the stomatal rows is difficult to observe. Usually, there are 2 guard cells, 2 polar and 2 lateral subsidiary cells per stomatal complex. The stomatal complexes were probably collapsed and it is impossible to distinguish cell walls from folds on the periclinal walls. In a few cases, guard cells have been preserved. They have a crescent shape, are 28-40 $\mu \mathrm{m}$ long and 12-14 $\mu \mathrm{m}$ wide (Pl. 2, Figs. e, f).

Remarks: GRAND'EURY (1877) described similar specimens with fine venation as Cordaites affinis. They are narrow, lanceolate leaves with sharp apices, about 200-300 $\mu \mathrm{m}$ long and $18-30 \mu \mathrm{m}$ wide. The widest part of the leaf is also approximately in the middle of the leaf. The dimensions of the leaves described here fit to this description, only they (Pl. 1, fig. 3) are a little wider $-36.5 \mathrm{~mm}$. The vein density is comparable with data from LEDRAN (1966): 50-60 per mm. Leaves of Cordaites affinis start gradually to widen from their base, the leaf on Pl. 1, fig. c widens more and thus resembles more closely Cordaites palmaeformis that is compared closely with previous species.

Cuticles prepared from the specimen on $\mathrm{Pl}$. 1, fig. c resemble the cuticles of Cordaites palmaeformis (ŠIMU゚NEK, 2015) with stomatal rows on both the abaxial and adaxial cuticles. Cuticles from the type material of Cordaites palmaeformis were also poorly preserved, however, the structure of the stomatal complexes of adaxial and abaxial cuticles has eventually been resolved. Cordaites cf. affinis from Otovice and Cordaites palmaeformis from Walbrzych are both amphistomatic leaves with stomata arranged in stomatal rows on both cuticles. However, it is still not possible to demonstrate that the specimen on Pl. 1, fig. c is Cordaites affinis, or if it belongs to Cordaites palmaeformis, because cells of the sto- matal rows are poorly preserved and a comparison is not possible, therefore these specimens are named as Cordaites cf. affinis.

LEDRAN $(1960,1966)$ studied cuticles from cordaitaleans from France which were also poorly preserved. Her drawings of the cuticles show that the stomatal complexes are drawn as cyclocytic complexes with 4 or 5 equal subsidiary cells around the stomatal pore. Such a stomatal type is not known from cordaitaleans. Abaxial cuticles of Cordaites angulosostriatus also have stomatal rows (LEDRAN, 1960, 1966). Its reconstruction by RABITZ (1966) is more realistic. The adaxial cuticle of Cordaites angulosostriatus has dispersed stomatal complexes.

BARTHEL (1964) published Cordaites sp. type 4 from the Asturian of Zwickau that also has dark stomatal rows on abaxial cuticles and dispersed stomata on adaxial cuticles. Cordaites regularis described by LEDRAN (1966) has stomatal rows on the abaxial cuticle and dispersed stomata on the adaxial cuticle. $\mathrm{Cu}-$ ticles from the other nine cordaitalean species described by LEDRAN (1966) have either stomatiferous bands or irregular stomatal rows on the abaxial cuticles.

Several cordaitalean species have been described that have stomatal rows on the abaxial and adaxial cuticles: e.g. Cordaites principalis type 2 ZODROW et al. (2000) from the Bolsovian of Bay St. George, Newfoundland, Canada (see also ŠIMU゚NEK, 2007). Similar cuticles are also known from the Bolsovian of the Czech Republic - Cordaites rerichensis (ŠIMŮNEK, 2007) and from the Asturian of the Heřmanova Hut' locality - Cordaites pilsensis (ŠIMU゚NEK, 2007, 2008) and from the Blažkovice locality - Cordaites blazkovicensis ŠIMŮNEK, 2007; however, these species have a "Cordaites principalis-type" venation (ŠIMŮNEK, 2007, 2008). The Stephanian species Cordaites risutensis ŠIMŮNEK, 2007 is similar to Cordaites cf. affinis having fine venation with $50-60$ veins per $\mathrm{cm}$, however the stomatal densities within the stomatal rows are not so high and individual stomatal complexes are separated by ordinary epidermal cells. The last comparable species is Cordaites radvanicensis ŠIMŮNEK, 2007 from the Stephanian of the Intrasudetic Basin, Czech Republic. The type material consists of leaves less than $30 \mathrm{~mm}$ wide with a venation consisting of 30 thick veins per mm and 2-3 thin sclerotic bundles between each of the two thick veins. However, the "thick" veins are not as thick as those in Cordaites principalis. When we count all the veins, there are 90 veins per $\mathrm{cm}$. A comparison of the cuticles is interesting: it was demonstrated in Cordaites radvanicensis that on the adaxial cuticle there are dark stomatiferous bands $120-160 \mathrm{~mm}$ wide, separated by light non-stomatiferous bands $60-80 \mathrm{~mm}$ wide. The dark stomatal rows of the abaxial cuticles are $50-70 \mathrm{~mm}$ wide and are separated by $50-80 \mathrm{~mm}$ wide non-stomatiferous bands. The data from the abaxial cuticle do not fully compare with Cordaites cf. affinis, but dark bands on the adaxial and abaxial cuticles are common for both species. It is possible that the specimen from Otovice, Černý potok, belongs to Cordaites radvanicensis ŠIMŮNEK, 2007. The guard cells of Cordaites cf. affinis are 28-40 mm long and the guard cells of Cordaites radvanicensis are 25-38 mm long (ŠIMU゚NEK, 2007).

\section{Cordaites cf. roesslerianus GEINITZ, 1862}

(Fig. 2f, l; PI. 3, Figs. d-f)

1862 Cordaites roesslerianus n. sp.; GEINITZ: p. 149, pl. 35, fig. 5.

Material: Museum of East Bohemia, Hradec Králové, specimen No. 74575 .

Description: The leaf fragment is $71.5 \mathrm{~mm}$ long and $15 \mathrm{~mm}$ wide; the margins are non-parallel, but the base and apex not preserved. 
The venation differs from all previously mentioned species. The leaf relief is three-dimensional with prominent ribs and grooves that make prominent veins in oblique light; vein density 20 per $\mathrm{cm}$ of the leaf (Pl. 3, Fig. e). Thin veins were not observed.

Remarks: The incomplete nature of the specimen renders the correct determination problematical. Cordaites roesslerianus GEINITZ are also preserved in fragments up to $120 \mathrm{~mm}$ long and $15-20 \mathrm{~mm}$ wide is similar. According to GEINITZ (1862), the vein density is 20-22 veins per $\mathrm{cm}$. Cuticle macerations of Cordaites cf. roesslerianus were unsuccessful, with only the dark and light bands being discernible (Pl. 3, Fig. f). Further maceration resulted in destruction of the cuticles. The dark bands that probably reflect vascular bundles are $370-500 \mathrm{~mm}$ wide and the light bands are only 170-300 mm wide. No sclerotic (thin) bundles were observed.

The other comparable species is Cordaites principalis (GERMAR) GEINITZ. Its holotype is preserved as a bunch of 32 leaves, 350-410 $\mathrm{mm}$ long and $15-36 \mathrm{~mm}$ wide. The leaf margins are slightly bent, as in the currently described specimen. The vein density of Cordaites principalis is 20-25 veins per $\mathrm{cm}$ (ŠIMU゚NEK, 2015), which is also in concordance with the presently described specimen. However, the ridges in Cordaites principalis are more prominent and the places between the ridges are flatter. Perhaps $C$. roesslerianus is conspecific with $C$. principalis, however it is difficult to prove because the base and apex of $C$. roesslerianus is not preserved.

LIPPS (1927) described Cordaites principalis from the Lower Permian of the Intrasudetic Basin (Unislaw Ślaski locality). It has 18-24 veins per $\mathrm{cm}$ an 3-4 sclerotic bundles between 2 veins.

\section{Cordaites cf. foliolatus GRAND’EURY}

(Fig. 2g; PI. 3, Fig. g)

\section{Cordaites foliolatus GRAND`EURY; GRAND`EURY:} p. 219 , pl. XXI, fig. 3

Material: A single specimen from the Otovice locality is stored in the National Museum, Prague.

Description: The leaf is small, narrow, $69.5 \mathrm{~mm}$ long and $13 \mathrm{~mm}$ wide. The base is $9 \mathrm{~mm}$ wide. The apex is blunt. The venation is not prominent, fine, about 40 veins per $\mathrm{cm}$.

Remarks: This specimen to some extent resembles Cordaites foliolatus GRAND'EURY. Proportionally, the specimen from the Otovice is much more slender than the GRAND'EURY type specimens of Cordaites foliolatus, which have a narrower base $(5-7 \mathrm{~mm})$ and wider leaves $(10-25 \mathrm{~mm})$. Length/width ratio of this specimen is 5.4, whereas in GRAND'EURY's specimens it is around 4, and the apex is blunt to rounded, and the venation is prominent with 30 veins per $\mathrm{cm}$ and $4-6$ sclerotic bundles between each pair of veins. It is also possible that the described specimen represents a juvenile leaf of some long-leaved form, therefore it is described here as Cordaites cf. foliolatus GRAND'EURY

\section{Cordaites sp. A}

(Fig. 2d, e; PI. 3, Figs. a-c)

Material: Two fragments, stored in the National Museum, Prague. One represents the basal part and the other an apical part. They probably come from different leaves but may belong to one species.

Description: The fragment from the basal part of a leaf is $51 \mathrm{~mm}$ long and only $12 \mathrm{~mm}$ wide near the base. The leaf widens relatively progressively from the base. The second fragment represents a terminal part of a leaf. It is widest in the middle - about
$28 \mathrm{~mm}$ and suddenly narrowed to the bluntly pointed apex. The venation is fine, but not dense, about 25 veins per $\mathrm{cm}$ of the leaf.

Remarks: These specimens are difficult to compare with European Cordaites species. The estimated length of this leaf is $120-130 \mathrm{~mm}$. The small-leaved forms described by GRAND'EURY (1877) and LEDRAN (1966) are usually wider and have a blunt or rounded apex. MEYEN (1966) described some similar forms as Rufloria MEYEN. Some species have a large variability, mostly also with rounded apices, but there were other forms with nearly bluntly pointed apices. However, the venation of Rufloria is quite different from Cordaites species. The shape of the leaf is to some extant similar to Cordaites laevis (GRAND'EURY, 1877, pl. 25, fig. 2), which represents a drawing of a twig with leaves and fructifications. Some leaves have blunt apices but others have bluntly pointed apices. Cordaites laevis is maybe a nomen nudum, because GRAND'EURY (1877) wrote only that the twig is with Cordaites laevis leaves and Antholithes fructifications. There was no description of the holotype, but the drawing of GRAND'EURY (1877) was illustrated many times in subsequent publications and also on the internet.

\section{DISCUSSION}

It is difficult to classify Euramerican cordaitaleans only by macromorphological characteristics because of the variability of the leaves; e.g. IGNATIEV \& MEYEN (1989, fig. 6) showed great variability of Rufloria synensis. Similar leaves in the Euramerican Realm could be classified to several species, if we only take into account leaf shape. However, when studying cordaitaleans from one locality, we do not have such variability, e.g. in the case of Cordaites borassifolius (ŠIMŮNEK et al, 2009): the length of complete leaves is about 400-700 mm and width 35-90 cm, but the leaf shape remains practically the same.

Unfortunately, the localities near Otovice yielded specimens, where cuticular study was mostly not possible, so we are reliant on morphological features of cordaitalean leaves only. Still, it is not clear, if four or five Cordaites species are present in the Otovice localities. In this paper, five species are described, but it cannot be excluded that the specimens described here as Cordaites cf. beinertianus and $C$. cf. affinis do not belong to one species. The other species have different types of venation and Cordaites cf. foliolatus is small with a somewhat different leaf shape.

CROOKALL (1970) and BARTHEL (1976) realised the difficulty in the determination of Cordaites species. CROOKALL (1970) used the names of species, but BARTHEL (1976) considered all species (e.g. Cordaites borassifolius, C. principalis and C. palmaeformis) as "one" species, even if diversity of the cuticles was much higher, and BARTHEL (1976) and in subsequent papers (e.g. BARTHEL, 2009, 2016) preferred using "Cordaites sp.". RAGOT (1966) studied many French species of Stephanian and Permian age, but Cordaites cuticles were poorly preserved and did not contribute to the identification of individual species. Due to their variability in leaves and venation all species in this paper are determined with some uncertainty as "cf.", even if it is evident that more Cordaites species also occur in the Euramerican Permian (Asselian).

\section{FLORAL ASSEMBLAGE WITH Cordaites}

The flora of the Olivětín Member has been neglected in the palaeobotanical literature. Except for museum collections, there are unpublished works by RIEGER (1966) and BORS (1988). A taxonomic list compiled from these works and museum collections consists of: Sigillaria brardii BRONGNIART, Calamites gigas 
BRONGNIART, Palaeostachya thuringiaca (WEISS) BARTHEL, Cyathocarpus cyatheus (BRONGNIART) MOSBRUGGER, "Pecopteris" thuringiaca NĚMEJC, Autunia conferta (STERNBERG) KERP, A. naumannii (GUTBIER) KERP, Arnhardtia scheibei (GOTHAN) HAUBOLD et KERP, Sphenopteris germanica WEISS, Odontopteris lingulata (GÖPPERT) SCHIMPER, O. subcrenulata ROST, Neurodontopteris auriculata (BRONGNIART) POTONIÉ, Barthelopteris germarii (GIEBEL) ZODROW \& CLEAL, Taeniopteris coriacea GÖPPERT, T. cf. multinervia WEISS, Ernestiodendron filiciforme (SCHLOTHEIM ex STERNBERG) FLORIN, Culmitzschia angustifolia (FLORIN) CLEMENT-WESTERHOF, C. parvifolia (FLORIN) CLEMENT-WESTERHOF, C. intermedia (FLORIN) CLEMENT-WESTERHOF, C. speciosa (FLORIN) CLEMENT-WESTERHOF, Hermitia goeppertiana (FLORIN) CLEMENT-WESTERHOF, H. hirmeri (FLORIN) CLEMENT-WESTERHOF, Otovicia hypnoides (BRONGNIART) KERP et al., Walchia piniformis SCHLOTHEIM ex STERNBERG and Gomphostrobus bifidus GEINITZ.

This assemblage, which has been collected for more than 100 years, consists mainly of mesophilous to xerophilus elements. The hygrophilous species are practically limited to Sigillaria brardii and pecopteroids, which occur only very rarely. Walchian conifers dominate in the "walchia shales" and Autunia conferta is the most common species in the limestone facies. The other species occur partly in limestone and partly in the "walchia shales".

\section{CONCLUSION}

Cordaitaleans are not very common in the Permian of the Intrasudetic Basin. Seven specimens studied from the museum collections represent four or five species.

The first specimen has been classified as Cordaites cf. beinertianus. The type material of Cordaites beinertianus has a similar leaf shape, but the veins are sparser than in $C$. cf. beinertianus. The leaves of $C$. cf. beinertianus also resemble Cordaites palmaeformis, which has slightly narrower leaves but a comparable vein density.

A further two specimens were classified as Cordaites cf. affinis. They have a comparable shape and venation with the type material of Cordaites affinis GRAND'EURY. However, the apex is not preserved, so a comparison of this feature is not possible. One specimen, from which the cuticles have been studied, is wider than typical $C$. affinis and could also be compared with $C$. beinertianus. The cuticles of Cordaites $\mathrm{cf}$. affinis are poorly preserved, but stomatal rows and non-stomatiferous bands are distinguishable on both cuticles. The same cuticular type also occurs in Cordaites palmaeformis, and also C. radvanicensis, which is known from the Stephanian of the Intrasudetic Basin, but unfortunately only as fragments. The second specimen of Cordaites cf. affinis is narrow and compares well with the variability of Cordaites affinis. On the other hand, Cordaites palmaeformis can also have narrow leaves and all specimens mentioned here could represent the variability of one species similar to Cordaites palmaeformis or $C$. beinertianus.

The next specimen has been classified as Cordaites cf. roesslerianus. The determination is difficult because the base and apex are not preserved, however, the venation is very typical with wide and sparse veins. Such a venation is known from Cordaites roesslerianus and C. principalis.
Another specimen has been classified as Cordaites cf. foliolatus. It resembles the type specimens of that species, however, it has somewhat narrower leaves. It is the smallest cordaitalean leaf from the Otovice locality and could simply represent a juvenile leaf of one of the other species.

The final species is represented by two fragments: a basal and an apical part. It is a relatively short and wide leaf that is difficult to compare with any figured specimens, therefore it is named here as Cordaites sp. A. It resembles some leaves drawn by GRAND'EURY (1877) as Cordaites laevis, but there is neither description nor diagnosis for this species, so it must be considered as a nomen nudum. The venation of Cordaites sp. A differs from the venation of the previously mentioned specimens and therefore must belong to a different species.

\section{ACKNOWLEDGEMENT}

The author thanks S. ŠTAMBERG from the Museum of East Bohemia in Hradec Králové and M. LIBERTÍN from the National Museum in Prague for enabling the study of the collections from the Intrasudetic Basin. Thanks are also due to C. J. CLEAL from Cardiff UK for English checking and two anonymous reviewers for their reviews. This work was subsidised by the grant 2017/26/M/ST10/00646 (Polish National Science Centre).

\section{REFERENCES}

BARTHEL, M. (1962): Zur Kenntnis inkohlter Blätter der Gattung Cordaites Presl.Hallesches Jahrbuch für Mitteldeutsche. Erdgeschichte, 4, 37-39.

BARTHEL, M. (1964): Coniferen- und Cordaiten-Reste aus dem Rotliegenden des Döhlener Beckens.- Geologie, 13/1, 60-89.

BARTHEL, M. (1976): Die Rotliegendflora Sachsens.- Abhandlungen des Staatlichen Museums für Mineralogie und Geologie Dresden, 24, 1-190, Dresden.

BARTHEL, M. (2009): Die Rotliegendflora des Thüringer Waldes.- Veröffentlichungen Naturhistorisches Museum Schleusingen, Sonderveröffentlichung 2009 (Zusammendruck von Kapiteln aus den Jahrgängen 2003 - 2008). Schleusingen.

BARTHEL, M. (2016): Die Rotliegendflora der Döhlen-Formation.- Geologica Saxonica, 61(2), 105-238.

BORS, M. (1988): Litofaciální a biofaciální analýza svrchních olivětínských vrstev na Broumovsku.- Dipl. thesis, Přírodovědecká fakulta UK, 67 p. Praha.

BOSSOWSKI, A. (1995): Lower Silesian Coal Basin.- In: ZDANOWSKI, A. \& ŻAKOWA, H. (eds.): The Carboniferous System in Poland.- Prace Panstwowego Instytuta Geologicznego, 148, 173-175.

BUREAU, E. (1914): Études des gîtes minéraux de la France, bassin houiller de la basse Loire: Paris, Ministère des Travaux Publics, v. 1, 433 p. (1910); v 2, 417 p.; Atlas, 80 pls. (1914).

CROOKALL, R. (1970): Fossil plants of the Carboniferous rocks of Great Britain.Memoirs of the Geological Survey of Great Britain $2^{\text {nd }}$ sect., Palaeontology, 4/6, 793-840.

FLORIN, R. (1931): Untersuchungen zur Stammesgeschichte der Coniferales und Cordaitales.- Kunglige Svenska Vetenskapsakademiens Handlingar, Ser. III, 10/1, $588 \mathrm{p}$.

GEINITZ, H.B. (1855): Die Versteinerungen der steinkohlenformation in Sachsen. Verlag W. Engelmann, Leipzig, 61 p.

GEINITZ, H.B. (1862): Dyas oder die Zechsteinformation und das Rotliegende. II. Die Pflanzen der Dyas und Geologisches. Verlag W. Engelmann, Leipzig, 342 p.

GÖPPERT, H.R. (1841-1846): Die Gattungen der fossiler Pflanzen.- Verlag von Henry und Geben, Bonn, p. 1-70, pls. 1-18 (1841); p. 71-118, pls. 1-18(1842); p. 119-154, pls. 1-20 (1846).

GÖPPERT, H.R. (1852): Fossile Flora des Übergangsgebirges.- Verhandlungen der kaiserlichen Leopoldinisch-Carolinischen Akademie der Naturforscher, Suppl. des 22 Bd. 1-299, Taf. 1-44, Breslau und Bonn.

GÖPPERT, H.R. (1864-1865): Die fossile Flora der Permischen Formation.- Palaeontographica, 12: 1-224, pls. 1-40 (1864); 12: 225-316, pls. 41-64 (1865). Cassel.

GRAND'EURY, C.F. (1877). Flore Carbonifëre du Départment de la Loire et du Centre de la France. - Prémiere Partie-Botanique Impemerie Nationale, Paris, 624 p.

IGNATIEV, I.A. \& MEJEN, S.V. (1989): Suchoviella - gen. nov. from the Permian of Angaraland and review of the systematics of Cordaitanthales.- Review of Palaeobotany and Palynology, 57, 313-339.

KERP, H. (1990): The study of fossil gymnosperms by means of cuticular analysis.Palaios, 5, 548-569. 
KERP, H. \& KRINGS, M. (1999): Light microscopy of cuticles. - In: JONES, T.P., ROWE, N.P. (eds.): Fossil Plants and Spores: Modern Techniques.- Geological Society, London, 52-56.

KRINGS, M. (2000): The use of biological stains in the analysis of late Palaeozoic pteridosperm cuticles.- Review of Palaeobotany and Palynology, 108, 143-150.

KRINGS, M. \& KERP, H. (1997): An improved method for obtaining large pteridosperm cuticles.- Review of Palaeobotany and Palynology, 96, 453-456.

LEDRAN, C. (1960): Sur les cuticules de Cordaïtales.- Bulletin de la Société géologique de France $7^{\mathrm{e}}$ série, t. II, 653-656.

LEDRAN, C. (1966): Contributions a l'étude des feuilles de Cordaitales.- Théses présentées a la Faculté des Sciences de l'Académie de Reims, Sér. 1, 1-154. Reims.

LIPPS, T. (1927): Zur Rotliegendflora von Langwaltersdorf (Niederschlesien).- Jahrbuch der Preußischen Geologischen Landesanstalt, 48, 567-592.

MEYEN, S.V. (1966): Kordaitovye verchnego paleozoja Severnoj Evrazii [Cordaiteans of the Upper Palaeozoic of North Eurasia].- Trudy Geologicheskogo Instituta Akademii. Nauk SSSR, 150, 5-184.

MEYEN, S.V. (1984): Basic features of gymnosperm systematics and phylogeny as shown by the fossil record.- Botanical Review, 50/1, 1-111.

OPLUŠTIL, S., SCHMITZ, M.S., KACHLÍK, V. \& ŠTAMBERG, S. (2016): Reassessment of lithostratigraphy, biostratigraphy, and volcanic activity of the Late Palaeozoic Intra-Sudetic, Krkonoše-Piedmont and Mnichovo Hradiště basins (Czech Republic) based on new U-Pb CA-ID-TIMS ages.- Bulletin of Geosciences, 91/2, 399-432.

RABITZ, G. (1966): Cordaiten aus dem flotzführenden Oberkarbon des Ruhrgebiets. - Fortschritte der Geologie Rheinland und Westfalen, 13, 303-316.

RENAULT, B. (1896): Bassin houiller et permien d'Autun et d'Épinac, flore fossile, 1, in: Études des gîtes mineraux de la France, IV, Imprimerie Nationale, 578 p., Atlas 1893, pls. 29- 89. Paris.
RIEGER, Z. (1966): Fytopaleontologický výzkum broumovského permu. - In Tásler, R. Základní geologický výzkum broumovského permu.-MS. Geofond, 33 p., Praha.

ŠIMŮNEK, Z. (2007): New Classification of the genus Cordaites from the Carboniferous and Permian of the Bohemian Massif, Based on Cuticle Micromorphology.Acta Musei Nationalis Pragae, Series B, Historia Naturalis, 62/3-4, 97-210,

ŠIMU゚NEK, Z. (2008): The Asturian and Cantabrian floral assemblages with Cordaites from the Plzeň Basin (Czech Republic).- Studia Geologica Polonica, 129, 51-80.

ŠIMŮNEK, Z. (2015): Cuticles of the Polish type material of Cordaites palmaeformis (Göppert) Weiss and a Cordaites principalis-like form from Germany, Pennsylvanian.- Review of Palaeobotany and Palynology, 223, 50-70.

ŠIMU゚NEK, Z., OPLUŠTIL, S. \& DRÁBKOVÁ, J. (2009): Cordaites borassifolius (Sternberg) Unger (Cordaitales) from the Radnice Basin (Bolsovian, Czech Republic).- Bulletin of Geosciences, 84/2, 301-336.

TÁSLER, R., ČADKOVÁ, Z., DVOŘÁK, J., FEDIUK, F., CHALOUPSKÝ, J., JETEL, J., KAISEROVÁ-KALIBOVÁ, M., PROUZA, V., SCHOVÁNKOVÁ-HRDLIČKOVÁ, D., STŘEDA, J., STŘíDA, M. \& ŠETLÍK, J. (1979): Geology of the Bohemian part of the Intra-Sudetic Basin. 296 p.- Academia, Praha. [in Czech with English summary]

UNGER, F. (1950): Genera et species plantarum fossilium.- Wilhelm Braunmüller, 627 p., Wien.

WEISS, C.E. (1869-72): Fossile Flora der jüngsten Steinkohlenformation und des Rotliegenden im Saar-Rhein-Gebiete.- Verlag A. Henry, 250 p., 20 pls., Bonn.

ZEILLER, R. (1886-88): Flore fossile du bassin houiller de Valencienes.- Études Gîtes minéraux France, 1-731 (text 1888), pls. 1-94 (Atlas 1886). Paris.

ZODROW, E.L., ŚIMU゚NEK, Z. \& BASHFORTH, A.R. (2000): New cuticular morphotypes of „Cordaites principalis (GERMAR) GEINITZ” from the Canadian Carboniferous Maritimes Basin.- Canadian Journal of Botany, 78/2, 135-148. 

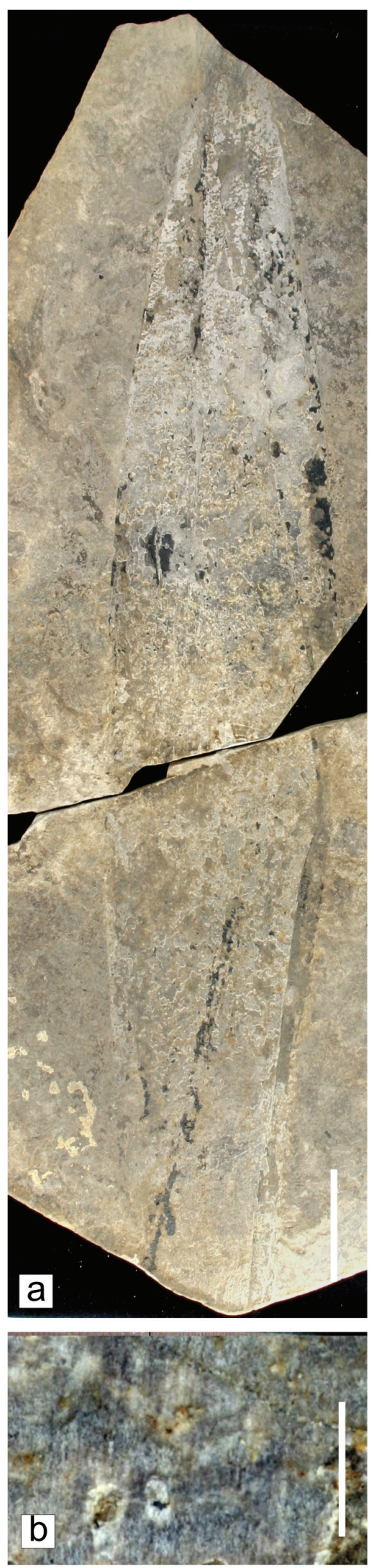
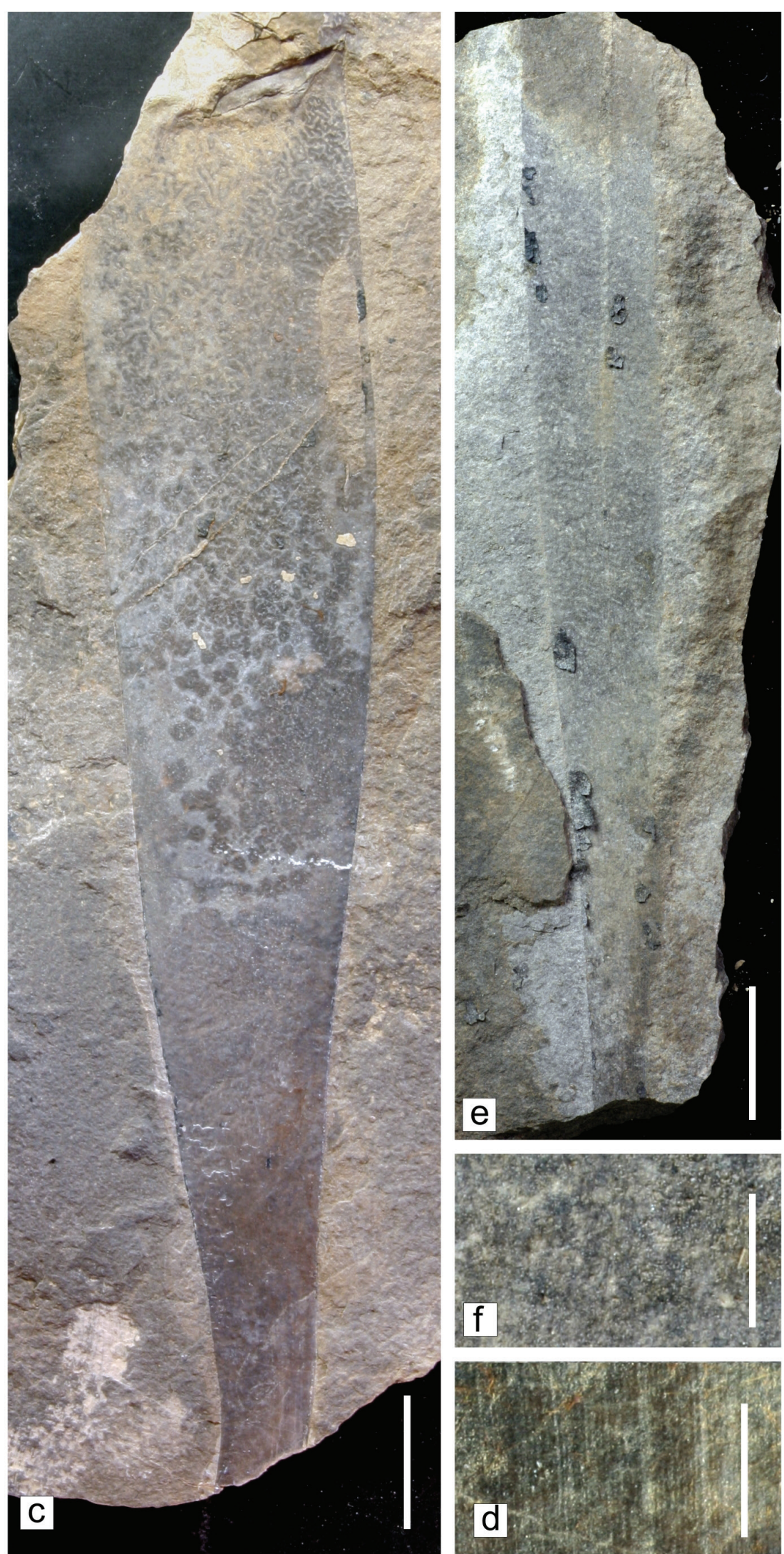

\section{Plate 1}

a - Cordaites cf. beinertianus (GÖPPERT) GRAND'EURY, coll. National Museum, Prague, no. E 7601, scale bar $=5 \mathrm{~cm}$.

b - Venation of the leaf from Fig. a., scale bar $=2 \mathrm{~mm}$

c - A leaf of Cordaites cf. affinis GRAND'EURY, coll. Museum of Eastern Bohemia, HRADEC KRÁLOVÉ, no. 74574 , scale bar $=2 \mathrm{~cm}$

d - Venation of the leaf from Fig. c., scale bar $=2 \mathrm{~mm}$

e - A leaf of Cordaites cf. affinis GRAND'EURY, coll. National Museum, Prague, no. E 7601, scale bar $=2 \mathrm{~cm}$

f - Venation of the leaf from Fig. e., scale bar $=2 \mathrm{~mm}$ 

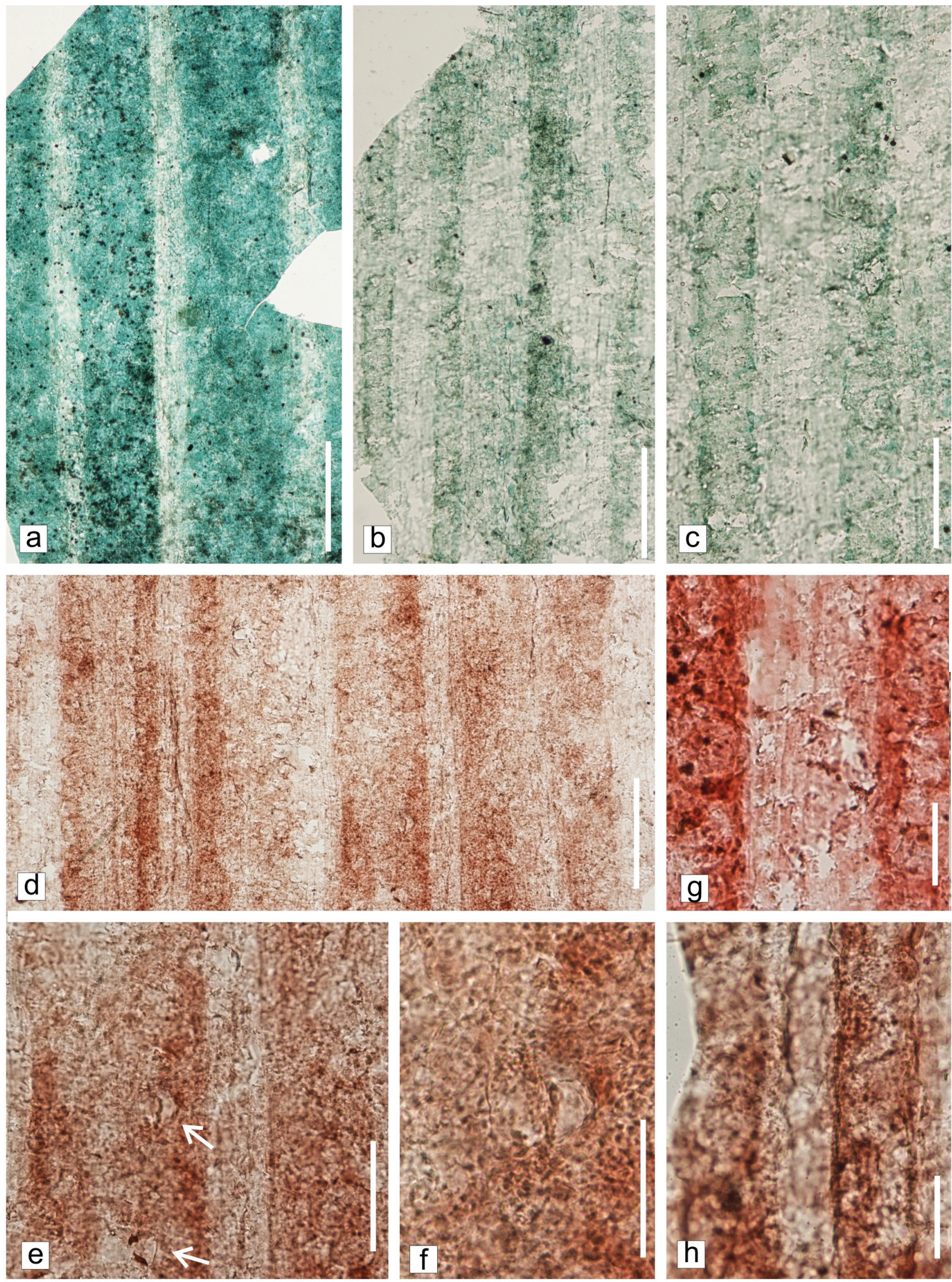

Plate 2

Cuticles of Cordaites cf. affinis GRAND'EURY from the leaf figured on PI. 1, Fig. c.

a - b Adaxial and abaxial cuticle from the same leaf fragment. Slide $698 / 13$, scale bar $=200 \mu \mathrm{m}$

c - h Abaxial cuticles. c. Detail from Fig. b. with two stomatal rows and non-stomatiferous bands. Scale bar $=100 \mu \mathrm{m}$. d. Abaxial cuticle with many stomatal rows. Slide 698/15, scale bar $=200 \mu \mathrm{m}$. e. Close up of Fig. d. with guard cells (arrow). Scale bar $=100 \mu \mathrm{m}$. f. Close up of two guard cells from Fig. e. Scale bar $=50 \mu \mathrm{m}$. g- $\mathbf{h}$ Two stomatal rows and a non-stomatiferous band, Slides. g. 698/7; h. 698/14, scale bar $=50 \mu \mathrm{m}$. 

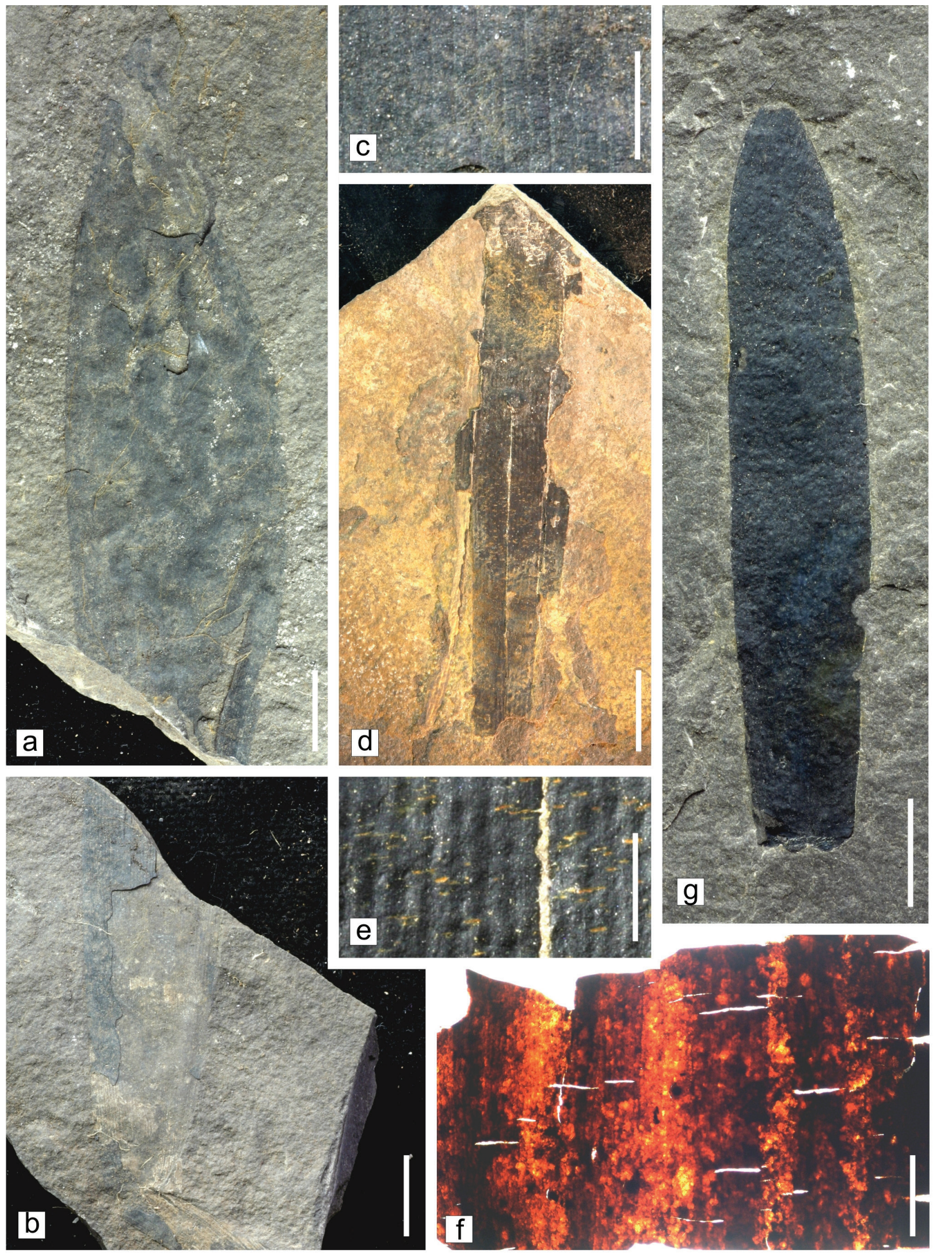

\section{1}
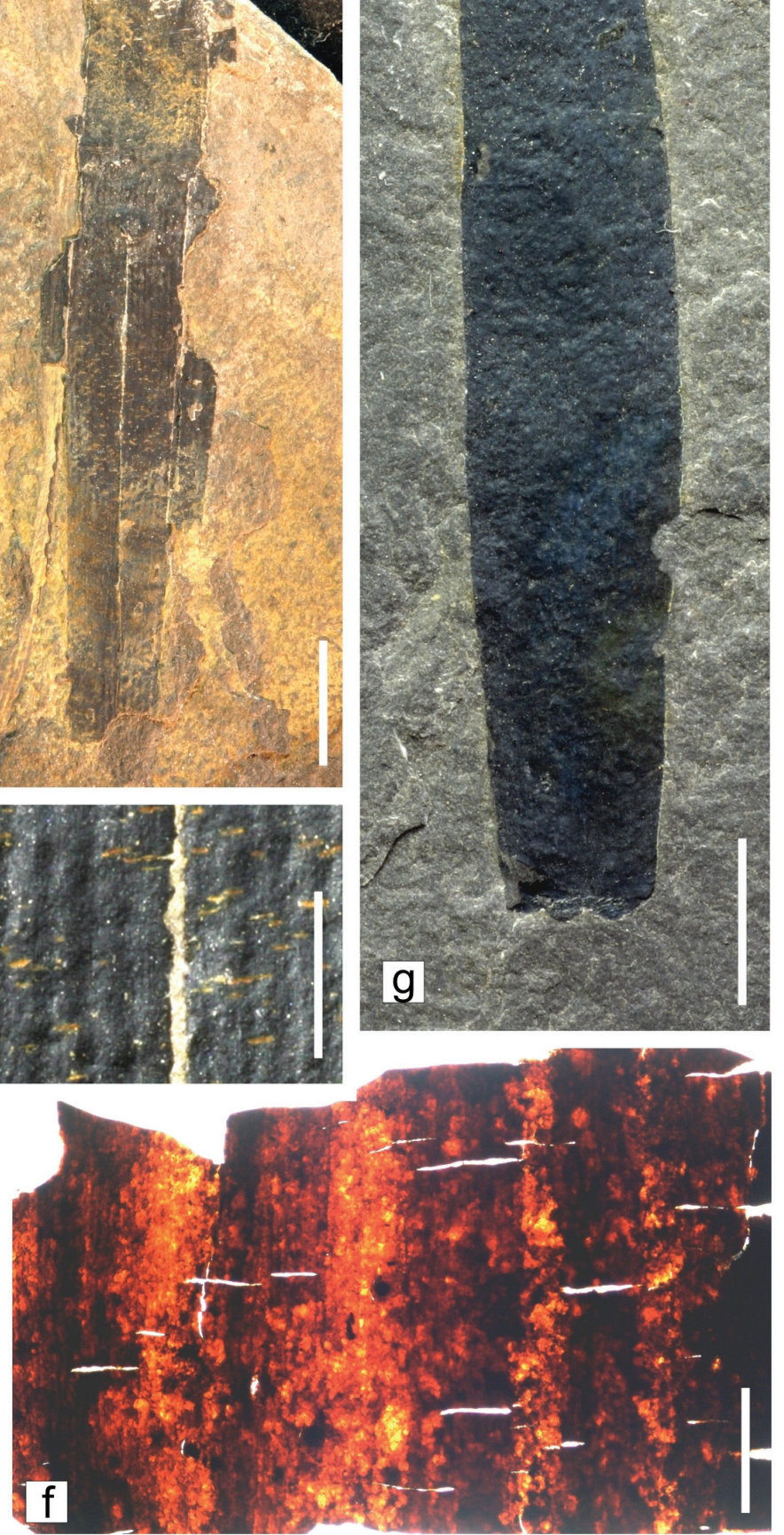

Plate 3

a - c Cordaites sp. A; a. Terminal part of the leaf, b. Basal part of the leaf, coll. National Museum, Praque, no. E 7602 and E 7603, (a and b- scale bar $=1 \mathrm{~cm})$, c. Close up of the venation, scale bar $=2 \mathrm{~mm}$.

d - $\mathbf{f}$ Cordaites cf. roesslerianus GEINITZ. d. Fragment of the leaf, coll. Museum of Eastern Bohemia, HRADEC KRÁLOVÉ, no. 74575, scale bar $=1 \mathrm{~cm}$, e. Close up of the venation, scale bar $=2 \mathrm{~mm}$, f. Macerated leaf fragment with veins (vascular bundles) and tissue between them. Slide 700/3, scale bar $=500 \mu \mathrm{m}$.

g Cordaites cf. foliolatus GRAND'EURY, coll. National Museum, Prague, no. E 7599, scale bar $=1 \mathrm{~cm}$. 